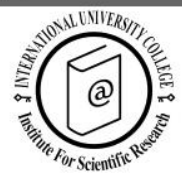

\title{
Creating value through sustainable business practices
}

\author{
Christine Lim $^{1 *}$, Yong Xin Chong ${ }^{2}$ and Melissa Sutjipto ${ }^{2}$
}

Received: 03/10/2011 Accepted: 25/01/2012

\footnotetext{
${ }^{1}$ Division of Marketing \& International Business, Nanyang Business School, Nanyang Technological University, S3-B2B-65, 50 Nanyang Avenue, Sngapore 639798; phone: +65 6790 4669, fax: +65 6794 1146, e-mail: christinelim@ntu.edu.sg

${ }^{2}$ Waikato Management School, University of Waikato, New Zealand

* Corresponding author
}

\begin{abstract}
The objective of this paper is to undertake a case study of Auckland International Airport and to examine how its sustainable business practices can create stakeholder value. Auckland Airport is the largest airport and the main gateway into New Zealand for international tourists. The paper investigates the impact of corporate growth-strategy announcement on the formation of a joint venture to build a 4-star airport hotel using an event study approach. The new hotel creates economic value to Auckland Airport as it is expected to generate considerable long term tourism revenue to the company. Additionally, it can stimulate economic growth and employment for the Auckland region as its proximity to the largest airport in the country attracts airline crews and transit passengers, and the hotel offers meeting facilities for MICE tourism. We found that the New Zealand share market's reaction to the hotel joint venture announcement on 23 July, 2009, as proxied by the stock returns, to be significant. Economic value creation or business profitability of a firm can be used to create societal value. Auckland International Airport has invested in socially responsible environmental and socio-cultural initiatives to create value for its stakeholders, as discussed in the latter half of the study.
\end{abstract}

(C) 2012 International University College. All rights reserved

Keywords: Auckland International Airport, sustainable practices, hotel joint venture announcement, event study, green technology, Maori culture

Citation: Lim, C., Y. Chong, M. Sutjipto (2012) Creating value through sustainable business practices. European Journal of Tourism Research 5(2), pp. 118-128

\section{Introduction}

The primary purpose of marketing is to create growth and improve earnings for the firm. Growing the business is necessary to increase value for a company. Marketing strategy formulation based on creating value should focus on building tangible as well as intangible assets for the company. The objective of this paper is to undertake a case study of Auckland International Airport (AIA) and to examine how its sustainable business practices to achieve economic/financial, environmental and social triple bottom line, can contribute to creating stakeholder value. To embrace corporate social responsibility, firms are expected to operate sustainably and/or seen to be committed to 
sustainability. Invariably, firms have adopted sustainable business practices as innovative marketing strategy to grow their business and to position themselves in the marketplace (Obermiller, 2008).

Tourism and travel have been recognised as major contributors to economic development, but also as possessing enormous potential in damaging the environment (Swarbrooke \& Horner, 2007). Sustainability is therefore one of the most important aspects within the tourism industry that should be carefully monitored to ensure that sustainable management is applied effectively and efficiently (Williams, 1998).

Auckland International Airport which is located in the north island of New Zealand, is the largest airport in the country, and Australasia's second busiest international airport. It is also the main gateway into New Zealand for international tourists. AIA was officially formed in 1988 when the New Zealand Government corporatized the airport. It became a limited liability public company and was listed on the New Zealand Stock Exchange on $28^{\text {th }}$ July 1998, following the Government's decision to sell its majority interest in the company. The following year, the company was listed on the Australian Stock Exchange (AIAL, 1999).

The airport is now owned and operated by the Auckland International Airport Limited (AIAL) with a market capitalisation of more than NZ\$2.7 billion (given by the share price times the number of AIA shares issued/outstanding in December 2010). AIA shares have fluctuated in quantity and value since the recent global financial crisis and recession, which has inevitably affected the market value of the company. The market value of the company's shares is based on investors' expectations of the cash-generating abilities of the business.

AIA is one of the most important corporations in New Zealand, generating NZ\$19 billion in output to the national economy (which is equivalent to $13.7 \%$ of GDP) and creating over 280,000 jobs (or $15.4 \%$ of national employment) annually. At the regional level, AIA has contributed $25.1 \%$ of output and $25.2 \%$ of employment annually to the Auckland economy (AIAL, 2007). Auckland, also known as the "City of Sails", is the largest city and the business capital of New Zealand. It is located in the fastest growing region, which also accounts for more than one-third of the country's economy.

Besides tourism, Auckland Airport provides a wide range of export and import services as it is the leading provider of transport and freight infrastructure in the country. AIA has also contributed to the Auckland regional economy through infrastructure development. The company owns large land holdings around the airport and it has developed them for recreational, retail and aeronautical businesses. AIA has continued to develop their businesses to increase shareholder returns. Figures 1 and 2 show the various sources of economic contribution and shareholder returns of AIAL, respectively.

Tourism is New Zealand largest export industry which accounts for $\$ 9.7$ billion of GDP, of which about $\$ 6.8$ billion is generated by AIA. Undoubtedly, AIA is closely linked with New Zealand tourism, playing an important role in the operation and development of tourism in the country as outlined in the New Zealand Tourism Strategy 2015 (Ministry of Tourism, 2007). Among others, the goal of the company is to help "grow" New Zealand tourism and business. The airport handles over 13 million (domestic and international) passengers each year and approximately $72 \%$ of international air passenger traffic in New Zealand (AIAL, 2009a).

The company has faced very challenging tourism business conditions in recent years, especially on long haul flights. The reduced demand for air travel in 2009 indicated the diminished levels of discretionary spending by consumers due to the global financial crisis and economic downturn. In 2009, total passenger movement at Auckland Airport was 13,012,917, a $1.4 \%$ decrease from 2008 . Total aircraft movements decreased by $1.8 \%$, with a $3.8 \%$ decline in domestic aircraft movements (Auckland Airport, 2009). Nonetheless, Auckland International Airport was ranked among the world's top ten airports in 2009 and the best in the Australia-Pacific region (Skytrax World Airport Awards, 2010). Additionally, it 


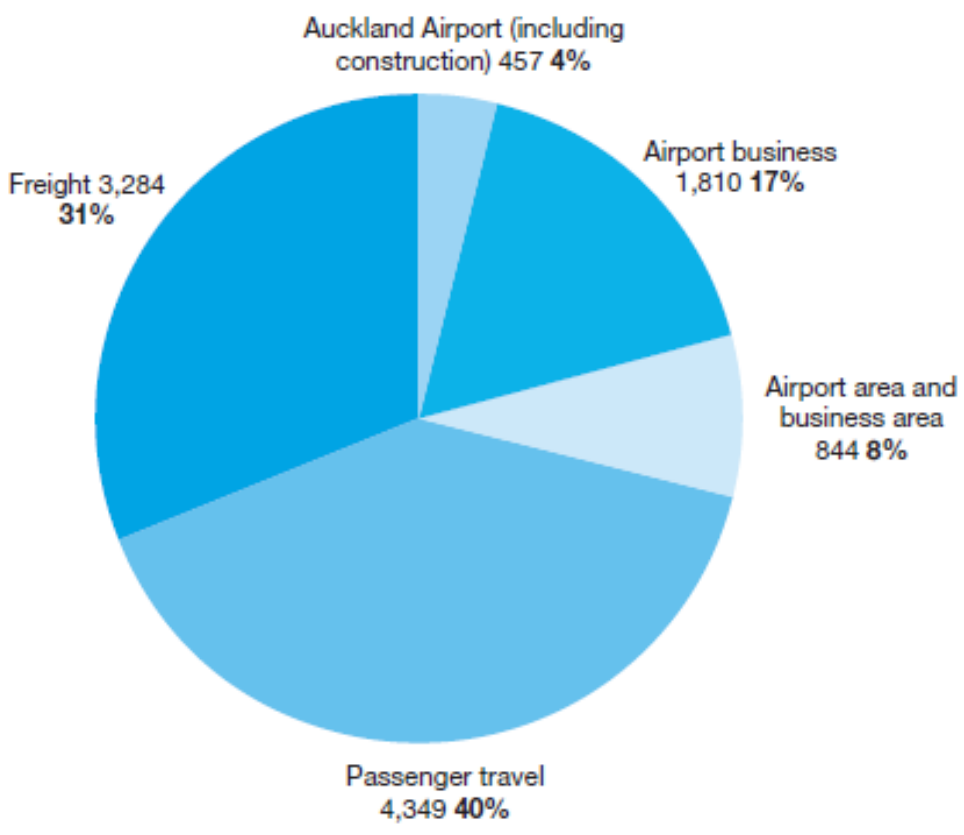

Figure 1. Sources of Economic Contribution, 2006 (NZ\$ m) Source: Auckland International Airport Limited (2007)

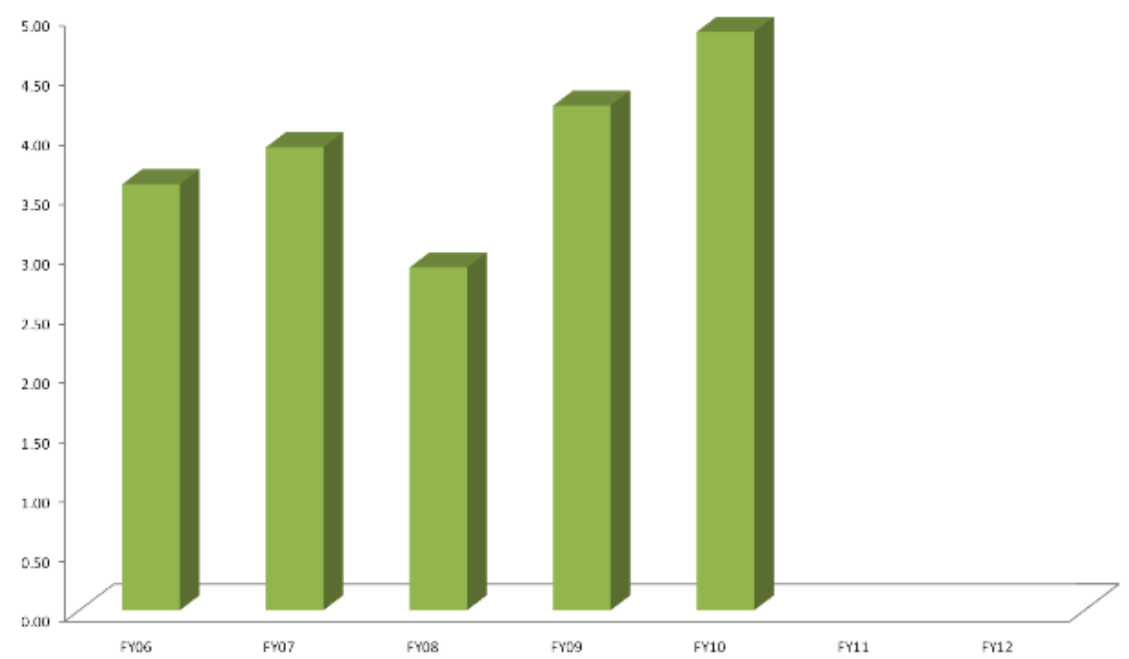

Figure 2. Total Shareholder Return, 2006-2010

Source: Auckland International Airport Limited (2010a)

has been awarded the Airport of the Year (under 15 million passengers annually) in the 2010 Frost \& Sullivan Asia Pacific Aerospace and Defence Awards (AIAL, 2010b).

In a large company like the AIAL, shareholder value is used to evaluate the performance of the various business units. The Group of 100 Incorporated (2003) which is an Association of Senior Executives representing major private and public enterprises in Australia, argued that economic/financial performance is the primary consideration in assessing business success (http://www.group100.com.au/publications/G10 
0 guide-tbl-reporting2003.pdf). Since the early 2000 s, there is much discussion about valuebased marketing (in relation to shareholder value), creating value for the company, and convincing stakeholders to invest their capital in the company's capabilities and future. Creating value is a continuous process that can be implemented with sustainable business practices and strategies. According to Doyle (2008), the main determinant of market value of a company is the ability of its management to capitalize on investment opportunities. AIAL has successful used its initiatives to create value for the company.

On July 23, 2009, Auckland International Airport Executives announced a joint venture to build a 4-star airport hotel (adjacent to the international terminal) by AIAL, Tainui Group Holdings and Accor Hospitality. Construction of the world class 263-roomed hotel, known as Novotel Auckland Airport, was completed before July, 2011, for the Rugby World Cup. It is estimated that 85,000 visitors would come to New Zealand for the 2011 Rugby World Cup (Tourism New Zealand, 2010). The hotel will showcase New Zealand's culture and heritage (AIAL, 2009b). Furthermore, the new airport hotel creates economic value to Auckland Airport as it is expected to generate considerable long term tourism revenue to the company. It can stimulate economic growth and employment for the Auckland region as its proximity to the largest airport in the country attracts airline crews and transit passengers, and the hotel offers meeting facilities for MICE tourism. It is also attractive to business tourists by minimising travel time between airport and hotel, and to passengers on early morning flights.

Tainui Group Holdings (TGH) is a New Zealand-owned company that manages the commercial assets of the Waikato-Tainui people. (Tainui is a confederation of four main Maori tribes (iwi) which settled in the central North Island of New Zealand). TGH was formed by Tainui Corporation Limited (TCL) and Tainui Development Limited (TDL) in 1999. TCL became the principal landlord of the properties which were returned to WaikatoTainui as part of the Waikato-Tainui Raupatu (land confiscation) settlement with the Crown while TDL was the development investment arm of the corporation (TGH, 2010a). Restructuring brought $\mathrm{TGH}$ into a single commercial operational arm in 2002. The major development projects and investment properties engaged by $\mathrm{TGH}$, among others, include the main shopping malls in Hamilton (namely, "The Base" and "Centreplace Mall"), Tainui Auckland Airport Hotel, the University of Waikato, the City Campus of the Waikato Institute of Technology (WINTEC), as well as the Huntly Power Station (TGH, 2010b).

Accor Hospitality is the largest and fastest growing hotel group in the Asia Pacific region, with more than 402 hotels in 19 countries (Accor, n.d.). In New Zealand alone, Accor owns 23 hotels, which includes a luxurious 5star Sofitel Hotel in Queenstown, 5 Novotel Hotels, 13 Mercure Hotels, 5 Ibis Hotels, 2 All Seasons Hotels and 1 hotel without a brand name (Accor, n.d.). Besides working in partnership with $\mathrm{TGH}$ in the Tainui Auckland Airport Hotel, Accor also has two other hotels located in Hamilton, namely Novotel Tainui Hotel and lbis Tainui Hotel, in which the Tainui Group Holdings is a major owner.

The rest of the paper is structured as follows. The literature review is presented in section 2. We will analyse the impact of AIAL decision to build a 4-star airport hotel, to be completed for the 2011 Rugby World Cup. In particular, we will examine the effect of the growth-strategy announcement on its share price using an event study approach in section 3 . Economic/financial value creation or business profitability can be used to create societal value. We will discuss some of Auckland Airport socially responsible environmental and social initiatives in sections 4 and 5 . Some concluding remarks are given in section 6 .

\section{Literature review - Event Study}

Changes in share price often reflect the positive or negative reactions/perception of investors regarding the company. In event study, a particular piece of news or a significant event related to a firm is called an event (Kwansa, 1994). Often, investors would react to events such as public announcements related to companies' operating results, mergers and acquisitions, corporate reorganisations, 
investments decisions, natural disasters and other economic impacts. Such public announcements or events tend to move stock prices as investors react to the potential attractiveness of (or lack thereof) the business. An event study is a statistical method which determines whether an event (already taken place) has a significant impact on the value of a firm or financial market. By assessing the abnormal return attributable to the event, we would be able to check for positive or negative reactions from the market.

Event studies are based on changes in stock price (index) which is a metric for measuring shareholder value or return in a firm (financial market performance). The event study methodology has been used extensively in finance, accounting and other areas of applied economics. The Efficient Market Hypothesis asserts that share prices reflect all available information and that they immediately adjust to reflect new information (Ross, Westerfield \& Jaffe, 2010). Hence the impact of a specific event on the market value of a firm can be observed by comparing the stock prices of the firm before and after the event. The total return on a stock has two components, namely the expected and the unexpected part of the return. When an announcement is made and it is a surprise, it will influence the unexpected/ unanticipated return on the stock.

The event study approach has also been used to evaluate professional and mega sporting events. Most of these studies examined the impact of the sporting events on the stock markets. For example, Krueger and Kennedy (1990) investigated the relationship between the stock market performance and the annual American Football Final. Ashton, Gerrard \& Hudson (2003) examined the relationship between the performance of the English national football team and changes in the FTSE 100 index between January 1984 and July 2002. Berman, Brooks \& Davidson (2000) analysed the impact of the selection announcement of Sydney as the host city for the 2000 Olympics on the Australian Securities Exchange. Veraros, Kasimati \& Dawson (2004) examined the impacts of the selection announcement for the 2004 Olympic Games on the stock markets of the two competing countries, Greece and Italy.

Unlike Berman et al. (2000) and Veraros et al. (2004), the research by Nishio, Lim \& Downward (2010) is more extensive. Their study analysed the host city selection announcement impact on the national stock markets of both the winning and runner-up countries for seven Summer Olympic Games between 1981 and 2005 and seven Winter Olympic Games between 1986 and 2007. In all these event studies, dummy variables in the regression models are used to capture the announcement impact.

Given that the event study method is easy to implement and it is increasingly used to assess managerial decision-making, the usefulness of this technique can be applied to analyse corporate events. Few tourism and/or hospitality studies have used the event study method to examine corporate events such as the formation of joint ventures on shareholder value. And unlike the aforementioned studies on sporting events which used dummy variables, we will determine whether there is an 'abnormal' stock price effect associated with the joint venture announcement of AIA.

\section{Data, method and results}

We examine the share price of Auckland International Airport Limited for the period 23 July 2007 to 23 July 2010 (see Figure 3). The sample period starts two years prior to the announcement date (event) on July 23, 2009, and provides a sufficient timeframe to monitor the share price movement one year after the announcement. For performance comparison, we also used the New Zealand Exchange (NZX) as the share market index and NZX Leisure and Tourism as the sector index. All stock prices and indices were obtained from Datex (also referred to as NZX Deep Archive).

The mean daily share price of Auckland International Airport (AIA) during this period was NZ\$2.10 while the median and mode prices were $\$ 1.93$ and $\$ 1.92$, respectively. The share price ranged from a low of $\$ 1.51$ to a high of $\$ 3.41$. Figure 4 shows the share prices of AIA two months on either side of the announcement. It would appear that the prices 


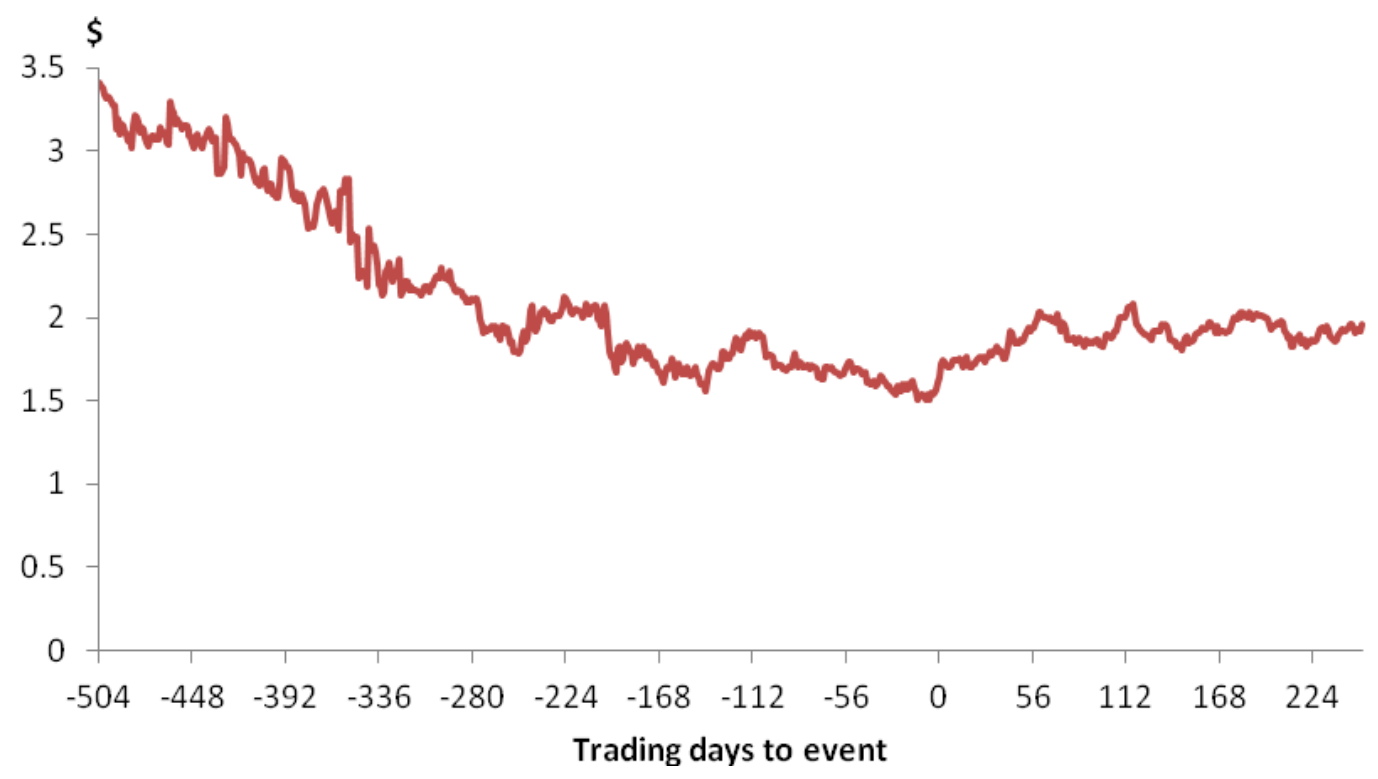

Figure 3. Auckland International Airport Share Price, 23 July 2007-23 July 2010

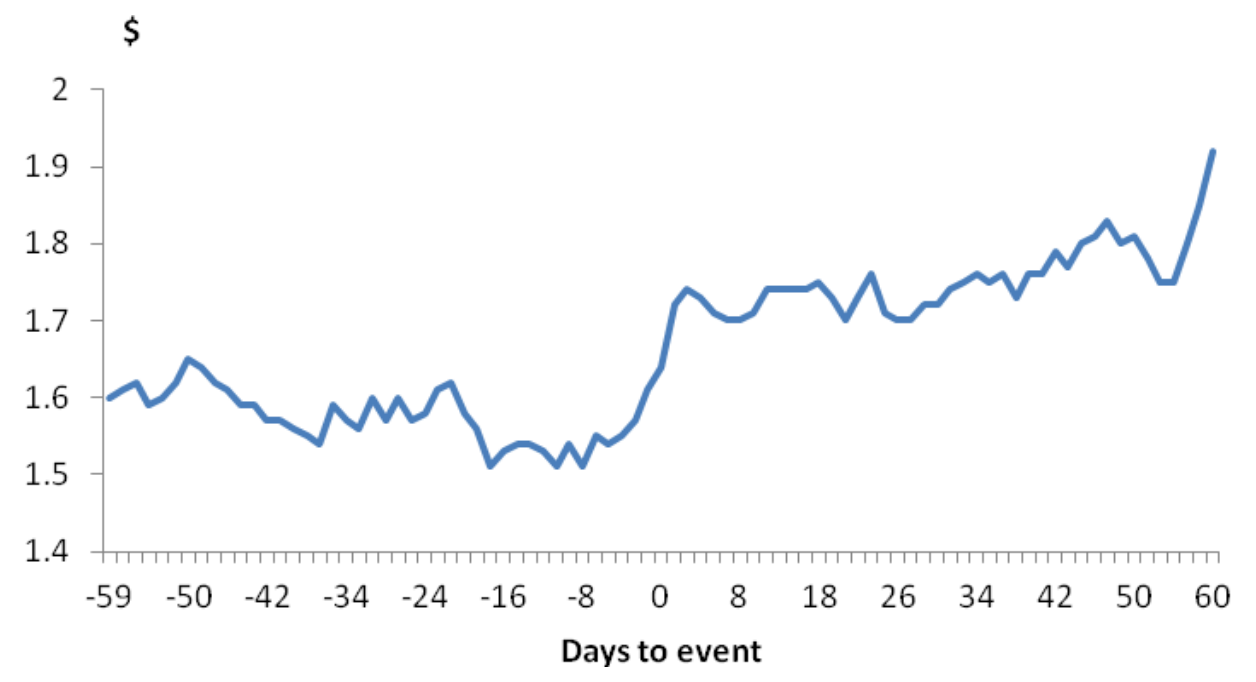

Figure 4. Auckland International Airport Share Price, 23 May - 21 September 2009

remained relatively stable on the days leading up to the event/announcement day (day 0 ).

On the days subsequent to the event, share prices seemed to trend upwards. AlA's closing share price on July 24, 2009 was quoted as $\$ 1.72$, an increase of $4.87 \%$ from the previous day's closing price of $\$ 1.64$. Taken on face value, this upward movement in share prices after the announcement could be interpreted as increased market optimism. However, such behaviour could be due to the influence of the overall share market. This being the case, it would be misleading to attribute price changes solely to the announcement of intent. 


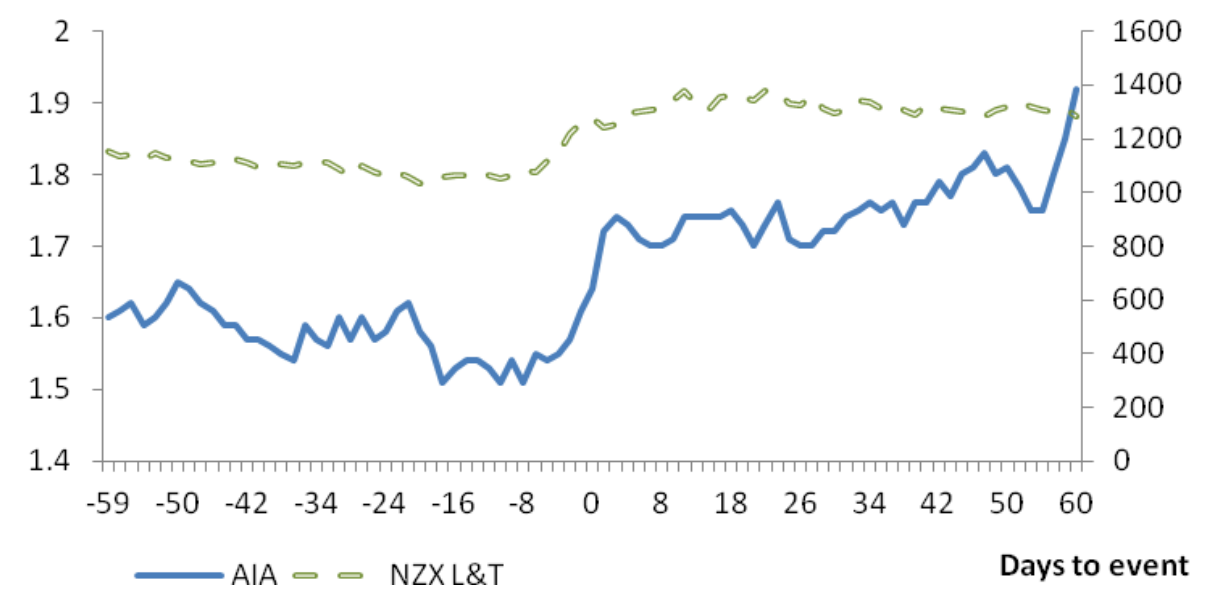

Figure 5A. Price Movement of AIA versus NZX Leisure \& Tourism Sector Index

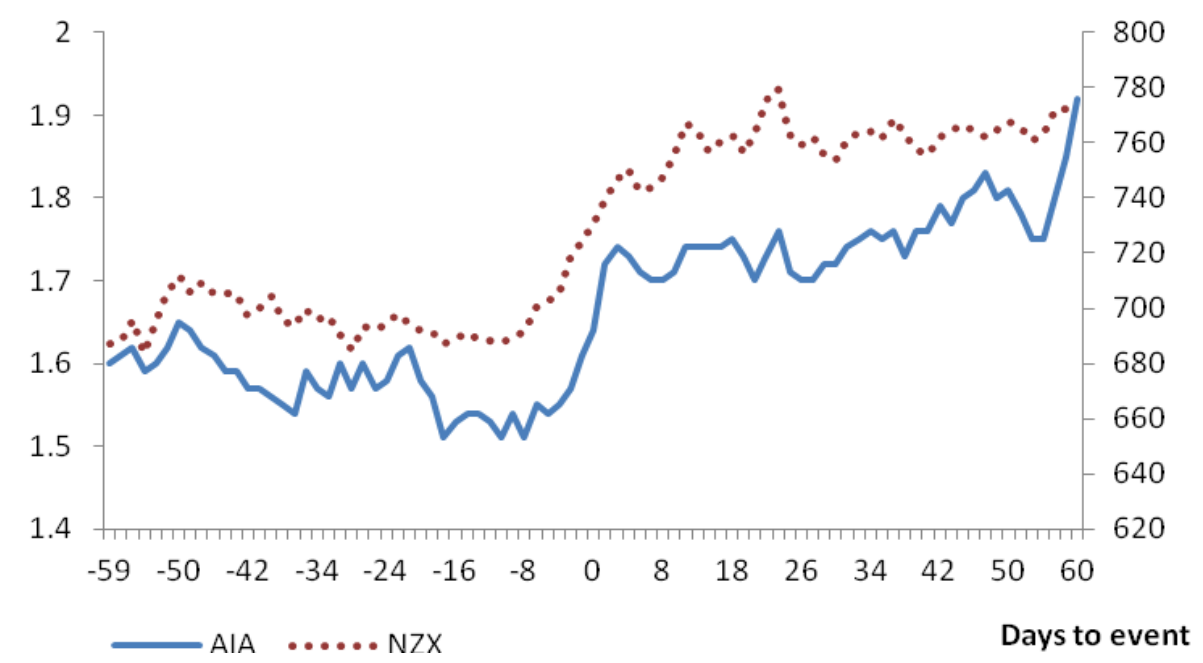

Figure 5B. Price Movement of AIA versus NZX Market Index

The performance of the company's share prices with those of the share market and sector indices is also analysed. Figures $5 A$ and $5 \mathrm{~B}$ show the price movement of AIA shares versus the NZX Leisure and Tourism sector index, and AIA share prices versus the NZX market index (proxy for market portfolio) in the 60 -day time window, respectively. We observe from Figure 5A that AIA shares experienced a sharper leap in value than the Leisure and Tourism sector index. From the lower panel, it would seem that the amount of movements of 124 the NZX market index and AIA share prices are approximately equal. From these observations, one would conclude that the announcement had no effect on share prices, as AIA shares were simply following the market trends. In order to examine the effects of the announcement on AIA share prices and the market as a whole, it is necessary to calculate the expected and abnormal returns of AIA share prices during the sample period. (We calculate the share price returns in dollars excluding dividends). 


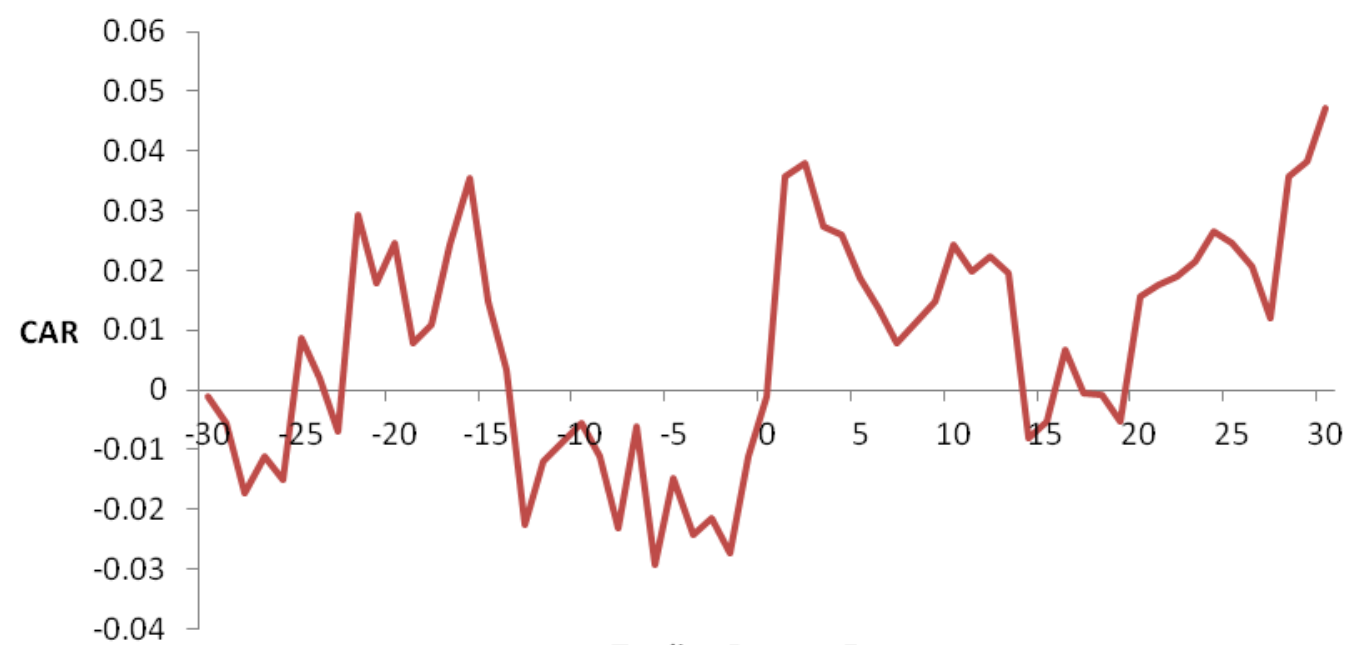

Trading Days to Event

Figure 6. Cumulative Abnormal Returns for AIA One Month Before and After the Announcement

Ordinary least squares (OLS) regression is used to estimate the impact of the announcement on the returns of AIA shares against NZX returns. We obtain the following linear relationship between the expected return $(E(R))$ and NZX returns $\left(R_{N Z X t}\right)$ with absolute t-ratios in parentheses:

$$
\begin{aligned}
& E(R)_{t}=0.00004+1.1271 R_{N Z X t} \\
& \text { (0.06) (15.59) }
\end{aligned}
$$

where:

$$
\begin{aligned}
& E(R)_{t}=\underset{\text { Expected return of AIA shares at }}{\text { time } t ;} \\
& R_{N Z X t}=\text { Market return at time } t .
\end{aligned}
$$

The estimated market return coefficient is positive and significant at the $5 \%$ level. The actual return, $R_{A C T t}$, is defined as the proportional change in the daily price index:

$$
R_{\text {ACTt }}=\frac{P_{t}-P_{t-1}}{P_{t-1}}
$$

Abnormal returns are computed by subtracting market return, $R_{M t}$, from actual returns:

$$
R_{A B t}=R_{A C T t}-R_{M t}
$$

Cumulative Abnormal Returns (CAR) are the sum of the previous and current day's abnormal returns:

$C A R_{1}=R_{A B 1}$, for $\mathrm{t}=1$; and
$C A R_{t}=C A R_{t-1}+R_{A B t}$, for $\mathrm{t} \geq 2$

Figure 6 illustrates AIA's cumulative abnormal returns one month before and after the announcement of the construction of the 4-star hotel. As shown on the graph, the biggest increase in cumulative returns was between 23 July 2009 and 24 July 2009 with a difference of $3.69 \%$.

While the main objective of AIA is to maximize the shareholders' (owners') return on equity, emphasis is also placed on environmental and social initiatives. For businesses to be successful in the future, they must create societal value. Some of the socially responsible environmental and socio-cultural initiatives of AIA will be discussed in the next sections.

\section{Environmental Sustainability}

The tourism industry is a contributor to climate change by generating greenhouse gas emissions through travellers' consumption of transport services, notably road and air transport, and high levels of energy consumption like air conditioning, heating and lighting in tourism establishments. As the aviation and tourism industries are called upon to take on the challenge of an authentic response to the climate change crisis, numerous flagship airports around the world 
have invested in innovations to reduce their carbon footprint. The installation of solar panels, and facilities to recycle rainwater and to reduce waste are among some of the green technology being adopted (Sims, 2008).

The Maori or indigenous people of New Zealand have been practising sustainability centuries before the concept was promoted in the 1970s (see United Nations Environment Program). New Zealand approach to sustainable tourism is guided by two key principles, namely kaitiakitanga and manaakitanga (Ministry of Tourism, 2007; Connell et al., 2009). The latter is Maori concepts which imply guardianship and responsibility, respectively. In fact, much of New Zealand Tourism Strategy 2015 used these concepts to develop both short and longterm strategies (Ministry of Tourism, 2007).

Auckland Airport has taken a leading role in the setting of sustainable standards in New Zealand, and protection and enhancement of the environment by using appropriate green technologies. Some of the environmental initiatives of AIA include the installation of solar panels on the roof to make the airport a sustainable building. The solar panels are about $300 \mathrm{~m}^{2}$ and they convert the sun's energy into electricity to provide power to the corridor lights in the international arrival terminal during the day. The energy gained throughout the year is equivalent to 16 days worth of power saving energy (Auckland Airport, 2008a).

In addition to implementing measures to reduce energy consumption, another environmental initiative of AIA is harvesting rainwater. Rainwater is collected from the international arrival terminal and stored in multiple water tanks located in the adjacent building. In this way, the recycled water can be used for the airconditioning cooling towers, which are the buildings' largest water users. By recycling the rainwater, this helps to reduce the amount of water mains needed by the airport and it is estimated that around $6000 \mathrm{~m}^{3}$ of water could be re-used each year (Auckland Airport, 2008a).

\section{Socio-cultural Initiatives}

In this section, we will discuss some of the socio-cultural initiatives of AIA for sustaining the indigenous culture. The '100\% Pure' logo on the portrayal of a clean green destination image and $100 \%$ pure quality experience, have certainly been very successful branding used by Tourism New Zealand to promote inbound tourism. New Zealand's Maori cultural heritage is the second major drawcard for international tourists, after its spectacular landscapes and natural environment. Extensive research has been conducted by Ryan on Maori culture and tourist experience in New Zealand (see for instance, Ryan 1997, 2002, 2006).

New Zealand's unique culture and heritage are showcased in the design and development of the airport, with much of the new international arrival area featuring iconic and cultural New Zealand imagery. Traditional Maori carvings also hold prominence in the international departure gate area. In this way, international visitors to New Zealand can gain increased awareness of, and appreciation for New Zealand indigenous/Maori culture. Through its partnership with Tainui, Auckland Airport also fosters the preservation of indigenous culture and heritage. This is evident in the 2003 construction of Te Manukanuka o Hoturoa, Auckland Airport's Maori Marae (traditional Maori meeting place). The latter is a symbol of the relationship the Airport has with the local tangata whenua (indigenous people). The Marae provides a cultural heart at the airport, a place to enhance and share Maori history with all domestic and international visitors. Another important function of the Marae is to provide a culturally sensitive venue for the collection of tupapaku (deceased) on their return to New Zealand (Auckland Airport, 2008b).

The above are some of the socio-cultural initiatives of Auckland Airport which demonstrate their commitment to corporate social responsibility in building and strengthening relationship with the Maori community at the local and national level. Tourists to New Zealand are fascinated by cultural tourism, particularly with regard to Maori culture. The partnership and collective effort of AIA and the Maori community in showcasing the unique culture and heritage of 
New Zealand is also important for promoting indigenous tourism.

\section{Conclusion}

In this paper we have discussed AIA sustainable business practices/strategies which include the use of appropriate green technology, their participation in promoting indigenous culture and their investment in the airport hotel joint venture. Understanding how the marketplace would react to some of these strategies is important. Using the event study approach, we have analysed investors' reaction to the joint venture announcement, which is both positive and significant.

As Doyle (2008) has pointed out, a company has environmental and social responsibilities, and that shareholders are not the only stakeholders in the business. The challenges faced by AIA have changed dramatically over the last 10 years, with different issues becoming more dominant than others, as awareness about issues such as global warming is increasing. AIA is actively working on sustainable tourism practices and 'greening' the airport, as well as living up to New Zealand's image as a "clean and green" destination. Its cost reduction and best practices benefit the environment and can enhance shareholder value.

The company has to carefully monitor the three-way balancing act of economic/financial, environmental and social sustainability in order to operate effectively and efficiently, while still being socially responsible for their business operations. Besides investing in green technology and building an airport hotel which are tangible assets, shareholder value is maximised by giving some attention to sociocultural initiatives. Similar to the concept of building customer relationships, supporting indigenous culture and building relationship/partnership with the indigenous community are associated with building intangible assets for Auckland Airport tourism business. Creating stakeholder value is about identifying opportunities and building meaningful relationships with stakeholders. These are marketing assets which can become key generators of long term profits and competitive advantage for AIA. By being a socially responsible corporation, AIA will continue to create and deliver value to its stakeholders.

\section{Acknowledgement}

The authors are very grateful to the anonymous reviewer for helpful comments and suggestions.

\section{References}

Accor (n.d.) Accor worldwide. URL: http://www.accor.com/en/group/accorworldwide.html. (Accessed on 26.3.2010)

Ashton, J., Gerrard, B. \& Hudson, R. (2003). Economic impact of national sporting success: Evidence from the London stock exchange. Applied Economics Letters, 10, 783-785.

Auckland Airport (2008a). Environmental management system. URL: http://www.aucklandairport.co.nz/SocialResponsibility/Environmentalmanagement-system.aspx. (Accessed on 15.3.2010)

Auckland Airport (2008b). Te Manukanuka o Hoturoa Marae. URL: http://www. airportmarae.co.nz/. (Accessed on 18.3.2010)

Auckland Airport (2009). Annual report 2009. URL:

http://www.aucklandairport.co.nz/report/c ompany_report.html. (Accessed on 18.2.2010)

Auckland International Airport Limited (1999). Annual report 1999. NZX Deep Archive database. (Accessed on 22.2.2010)

Auckland International Airport Limited (2007). Economic Impact of Auckland Airport. URL: http://www.auckland-airport.co. nz/. (Accessed on 7.3.2010)

Auckland International Airport Limited (2009a). Interesting facts. URL: http://www. aucklandairport.co.nz/. (Accessed on 26.2.2010)

Auckland International Airport Limited (2009b). New hotel for Auckland Airport [Press Release]. URL: http://www. aucklandairport.co.nz/. (Accessed on 22.2.2010)

Auckland International Airport Limited (2010a) Economic Performance. URL: http://www.aucklandairport.co.nz/SocialResponsibility/Sustainability-policy/ Sustainability-action-plan/AP4-Economic- 
Creating value through sustainable business practices.

performance.aspx. (Accessed on 7.3.2011)

Auckland International Airport Limited (2010b) Auckland Airport wins another global performance award [Press Release]. http://www.aucklandairport.co.nz/Corpora te/NewsAndMedia/AllMediaReleases/Auc kland-Airport-wins-another-globalperformance-award.aspx. (Accessed on 26.2.2011)

Berman, G., Brooks, R. \& Davidson, S. (2000). The Sydney Olympic Games announcement and Australian stock market reaction. Applied Economics Letters, 7, 781-784.

Connell, J., Page, S. J. \& Bentley, T. (2009). Towards sustainable tourism planning in New Zealand: Monitoring local government planning under the Resource Management Act. Tourism Management, 30, 867-877.

Doyle, P. (2008). Value-based marketing. Chichester: Wiley.

Gelbach, J. B., Helland, E. \& Klick, J. (2009). Valid inference in single-firm, singleevent studies. Robert Day School of Economics and Finance Research Paper No. 2009-17.

Group of 100 Incorporated (2003). Sustainability: A guide to triple bottom line reporting. URL: http://www. roup100.com.au/publications/G100_guid e-tbl-reporting2003.pdf. (Accessed on 10.9.2010)

Krueger, T. M. \& Kennedy, W. F. (1990). An examination of the super bowl stock market predictor. Journal of Finance, 45, 691-697.

Kwansa, F. A. (1994). Acquisitions, shareholder wealth and the lodging sector: 19801990. International Journal of Contemporary Hospitality Management, 6(6), 16-20.

Ministry of Tourism (2007). New Zealand tourism strategy 2015. Wellington: Ministry of Tourism.

Nishio, T., Lim, C. \& Downward, P. (2010) Olympics host city selection and its impact on stock markets. Journal of Hospitality and Tourism, 8(1), 35-50.

Obermiller, C. (2008). Sustainable business as marketing strategy. Innovative Marketing, 4(3), 20-27.
Ross, S. A., Westerfield, R. W. \& Jaffe, J. F. (2010). Corporate finance. Boston: Irwin McGraw-Hill. $9^{\text {th }}$ ed.

Ryan, C. (1997). Maori and tourism - a relationship of history, constitutions and rites. Journal of Sustainable Tourism, 5(4), 257-279.

Ryan, C. (2002). Tourism and cultural proximity: examples from New Zealand. Annals of Tourism Research, 29(4), 952-971.

Ryan, C. (2006). Experiencing cultural tourism: visitors at the Maori Arts and Crafts Institute, New Zealand. Journal of Travel Research 44, 308-317.

Sims, A. (2008). Airports check In with green innovations.

URL: http://www.greenbiz.com. (Accessed on 2.12.2010)

Skytrax World Airport Awards (2010). The Top 10 Airports in the world for 2009. URL: http://www.worldairportawards.com/Awar ds_2009/Airport2009.htm. (Accessed on 22.2.2010)

Swarbrooke, J. \& Horner, S. (2007). Consumer behaviour in tourism. Oxford: Butterworth-Heinemann. $2^{\text {nd }}$ ed.

Tainui Group Holdings Limited (2010a). About us: TGH Timeline. URL: http://www.tgh.co.nz/default.asp?sid=4\&c $\mathrm{id}=$ \&aid $=$. (Accessed on 26.3.2011)

Tainui Group Holdings Limited (2010b) . Top investments. URL: http://www.tgh.co.nz/default.asp?sid=4\&c $\mathrm{id}=26$ \&aid $=$. (Accessed on 26.3.2011)

Tourism New Zealand (2010). Rugby World Cup $2011 . \quad$ URL: http://www.tourismnewzealand.com/cam paigns/rwc-2011. (Accessed on 26.3.2010)

United Nations Environment Programme (1972). Report of the United Nations Conference on the Human Environment, Stockholm. URL:

http://www.unep.org/Documents.Multiling ual/Default.asp?DocumentID=97\&Articlel $\mathrm{D}=1496$. (Accessed on 15.11.2010)

Veraros, N., Kasimati, E. \& Dawson, P. (2004). The $2004 \quad$ Olympic Games announcement and its effect on the Athens and Milan stock exchanges. Applied Economics Letters 11, 749-753.

Williams, S. (1998). Tourism Geography. New York: Routledge. 